\title{
日英の土壇污染地としてのブラウンフィールドにかかわる \\ 法的枠組みと規模推計 \\ LEGAL FRAMEWORK AND ESTIMATED STOCK MEASUREMENT ON BROWNFIELD AS CONTAMINATED LAND IN ENGLAND AND JAPAN
}

\author{
高 橋 彰*, 阿部浩 和**, 大塚紀子***, 宮川智子**** \\ Akira TAKAHASHI, Hirokazu ABE, Noriko OTSUKA \\ and Tomoko MIYAGAWA
}

\begin{abstract}
This paper aims to identify current situation of soil contamination countermeasures for England and Japan. It examines the legal framework and estimated stock measurement on contaminated land between the two countries. The primary findings are as follows: 1 ) The main differences in the Acts for soil contamination between the two countries are found in triggers for inspection, initiatives and ways of handling the whole process of remediation; 2) The number of estimated contaminated sites in the both countries is approximately 330,000. And the rate of site investigations is approximately three times in England than that in Japan; 3) Regarding the soil contamination counter measure, Environmental Act (EPA1990) and planning system (Planning 1990) are closely and jointly well operated in England; and 4) In England the local authority needs to take a strategic approach to the inspection of sites within their district boundary under EPA1990 and each contaminated site is handled by a risk based approach (CLEA) on the comprehensive evaluation of pollutant linkage and land use.
\end{abstract}

Keywords : Contaminated land, Brownfield, Scale estimation, Legal framework, England and Japan compare 土垬污染地，ブラウンフィールド，法的枠組，推計規模，日英比較

\section{1.はじめに}

わが国において「ブラウンフィールド」は一般に工場跡地などで 土壌污染のために再利用がなされずに放置されている土地に対して 使われていることが多く、環境省の報告書 ${ }^{1)}$ では「土壌污染の存在、 あるいはその懸念から、本来、その土地が有する潜在的な価值より も著しく低い用途あるいは未利用となった土地」と定義している。 このようなブラウンフィールドは近年の社会産業構造の変化に伴う 工場跡地の増加とともに顕在化してきており、今後の効果的な土壌 污染対策のあり方が問われている。本論では日本と英国の土壌污染 に関連する法的枠組みと規模推計の比較を行うことで、わが国の土 壌污染対策の位置付けと今後のあり方を考察することを目的とする。

ここで、「ブラウンフィールド」は米国でもブラウンフィールド修 正法 ${ }^{2)}$ の中で「有害物質による土壌污染の存在、あるいはその可能 性によって再開発や再使用が困難な不動産を意味する注1)」と定義 されており、日本の環境省の説明とほぼ同義である。しかしながら 英国においては「ブラウンフィールド」の定義が日米と異なり、 S.Alker ${ }^{3)}$ は「これまでに開発され使用されていた土地で現在では (その一部あるいはすべてが）十分に利用されていない土地のこと を言い、空き地や放棄地、土壌污染地なども含まれる注2)」として
おり、English Partnerships（以下 EPS）注3) のブラウンフィール

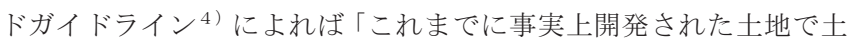
袞污染を含む様々な要因によって現在ではその利用が難しい土地注 4)」としていることから、英国における「ブラウンフィールド」は 必ずしも土壌污染だけでなくそれ以外の要因によるものも含めて、 現在十分利用されていない土地（低・未利用地）のことを意味して いる。

これまでに英国の土袞污染地或いはブラウンフィールドに関する いくつかの研究 ${ }^{5 \sim 8)}$ があるが、いずれもこのような定義上の齟龉 を取り立てて議論しているわけではなく規模推計の比較を行ってい るわけでもない。本論ではこのような定義の違いは日英における土 袞污染対策にかかわる法的枠組みと規模推計の比較を行う際の留意 点と考え、以下では環境省（日本）の定義による土壌污染地として のブラウンフィールドに限定する。

ここで英国を対象とするのは、わが国と同様にいずれも産業を中 心に発展してきた経緯があること、日本よりも古くから土壌污染対 策に取り組んできたこと、米国とは異なり国土面積が比較的小さく、 中でも唯一大陸近傍にある島国であり、近年のわが国における政策 の多くが英国を参考にしていることなど、英国の事例に学ぶことは
${ }^{*}$ 大阪大学大学院工学研究科 博士後期課程

** 大阪大学サイバーメディアセンター 教授・博士 (工学)

***ETH スイス連邦工科大学 スペース・ランドスケープ計画研究所 研究員・博士 (学術)

***** 和歌山大学システム工学部 准教授・博士(学術)
Graduate School of Engineering, Osaka University

Prof., Cybermedia Center, Osaka University, Ph. D. in Eng.

Researcher, Institute for Spatial and Landscape Development, ETH Zurich, Ph. D. in Urban Design

Assoc. Prof., Faculty of Systems Engineering, Wakayama University 
多く、わが国の土壌污染対策の位置づけを知る上でも意義は大きい。

\section{2. 方法}

本論ではまず両国の土壌污染対策の現状を把握するために、それ にかかわる法規制をもとに両国の土袞污染対策の制度上の枠組みの 違いを明らかにする。次に、両国の政府機関が公表している土壌污 染に係わるデータをもとに、両国の土袞污染地にかかわる推計規模、 調查実施件数、調查契機などを比較し、それらの結果をもとにわが 国における今後の土袞污染対策のあり方を考察する。

なお土壌污染の規制とその対策に関する法律は、日本では「土壌 污染対策法（2002 年）」により規定されており注5)、英国では主と して、「Environmental Protection Act 1990 (以下 EPA1990)」の 中の「Part II A 注 6)」において規定されている。ただし英国では上 記 EPA1990 以外に内閣府（ODPM）による都市計画ガイドライン (Planning Policy Statement) の中にも「Planning and Pollution Control (以下 PPS23))」として示されており、この規定は「Town and Country Planning 1990 (以下 Planning 1990)」による計画許 可の時点で適用される。ただ現政権においてこのPPS は廃止され NPPF (National Planning Policy Framework) が 2012 年 3 月 に発効されているが、まだその成果が公表されていないこともあり、 本論ではそれ以前の都市計画規制について考察する注7)。また、日 本の「土壌污染対策法」は 2010 年に改正が行われているため、本 論では改正後の法を「改正土壌污染対策法」とよび、改正以前のも のを「旧土壌污染対策法」として区別する注8)。

\section{3. 結果と考察}

\section{1 日英の土㙵污染対策関連法の比較}

両国の土壌污染対策に関する法律における一般的な調查・対策の フローを(1)調查契機、(2)土壌污染調查、(3)污染地指定、(4)対策・措

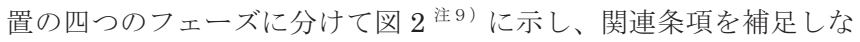
がら日英の制度上のフレームワークを比較する。

\section{(1)調査契機}

英国では EPA1990 と Planning1990 の 2 つの調查契機が存在す る。EPA1990では「地方自治体 (Local Authority)」に対して「污 染地 (Contaminated Land)」の指定のための調查計画の作成・公 表と管理区域の「污染地」に関する状況調查を行う義務が規定され ている（Part II A 78B-1 及び Circular Annex3,B9-A14）注 1 0)。ま た Planning1990 は英国の都市計画規制の基本となるもので、ほと んどの開発・建設行為は、「計画許可（Planning Permission）」を 必要とし、その申請時点で土袞污染調査義務が「土地所有者等

(Owner/Developer)」に課されている（PPS23 Annex2,2.17）。一 方、日本の「改正土壌污染対策法」では地方自治体に英国のような 「污染地」の調查義務は規定されておらず、A)特定施設使用廃止時 (改正法第三条) B)形質変更時（改正法第四条）、C)健康被害発生 時（改正法第五条）の 3 つの場合に土地所有者等注 1 1) に対して調 查義務が生じる注 12 2)。B)形質変更時の調查契機は 2010 年の法改正 時に追加された条項であり、それ以前は一部の地方自治体が定める 条例において大規模開発 $\left(3,000 \mathrm{~m}^{2}\right.$ 以上）に対する指導要綱で規定 されていた。

(2)土壤污染調査
土壌污染調查に関して、英国の EPA1990 では地方自治体がその 管理区域内において土壤污染の可能性があるサイトの使用履歴や現 地の状況を調査し、「污染物質リンケージ (pollutant linkage)」の 有無を把握する (Circular Annex3,A11) 注 13 )。この調查に関して、 地方自治体は人体一の健康リスクの高いサイトを優先する「戦略的 アプローチ (strategic approach) 注 14)」をとる必要があり (Circular Annex2,3.2)、こうしたアプローチは「環境庁（Environment Agency)」などに助言を求めながら各地方自治体によって作成され、 公表されるとしている (Circular Annex3,B11)。一方で日本の「改 正土赫污染対策法」では、先に述べた A)B)C)の調查契機に土地の所 有者等が土袞污染の調查義務を負う注 15$)$ 。 その中で B)の形質変更 時について当該敷地面積が $3000 \mathrm{~m}^{2}$ 以上の場合に土地所有者等が地 方自治体に届出ることにより、地方自治体は当該土地の使用履歴調 查等によって「污染のおそれ」の判断を行う(改正法第四条第二項)。 調查契機が A)特定施設使用廃止時、C)健康被害発生時の場合と B) で「污染のおそれ」があると判断された場合、土地所有者等は施行 規則に規定された方法注 16$)$ により土壤污染についての現地調查を 行うことになる。

以上日本では $3,000 \mathrm{~m}^{2}$ 未満の土地の形質変更による調查契機が存 在しないこと、また調查主体が土地の所有者等であるのに対し注 17)、 英国の Part II A では調査主体が地方自治体である点が異なる。

\section{(3)污染地の指定}

英国の EPA1990 では、地方自治体によって現地調查された「污 染物質リンケージ」の評価によって、「污染地（Contaminated Land）」の認定がなされる（Circular Annex2,3.33）。ここで「污染 物質リンケージ」とは「污染物質 (contaminant)」、「受容体 (receptor)」、「経路（pathway）」の関係であり、例えば「污染物 質」のみ基準を超過する土地が存在したとしても、「経路」が存在し なければ「重大な危害（significant harm）注18)」と判断されない ため「污染地」と認定されることはない（Circular Annex2,2.6）注 19)。また「污染地」の中で特に問題があると認められた土地は「特 別地（special site）」に指定され、環境庁の管理となり、それ以外 は地方自治体の管理となる（Part II A 78C）（図 1 参照）。また、 Planning1990 による調查契機では、土地所有者等による土壌污染 調査の結果、「許容できないリスク (unacceptable risks)」が明ら かとなった場合には地方自治体は調查結果に従って当該土地が Part II A による追加の措置が必要か否かの判断をしなければならな い(Circular Annex2,8.16, PPS23 Annex2,2.15)。この場合 Part II A と Planning1990 を管轄する機関は対策案を討議し「污染地」 の指定の是非を決定する必要がある（Circular Annex2,3.34）。

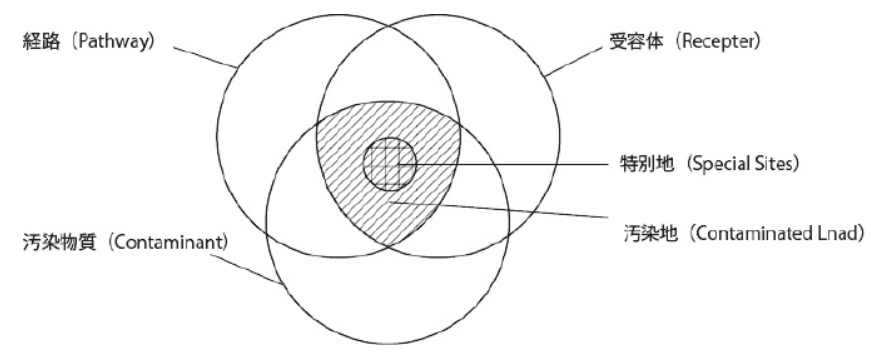

図 1 英国のP Part II A における「污染地」の概念図 
また、「DEFRA (Department for Environment, Food and Rural Affairs)」と「環境庁」によって、上述の「重大な危害（Part II A)」 と「容認できないリスク (Planning1990)」を科学的に評価するた めの専門的なデータセット「CLR (Contaminated Land Report) 注 20)」が準備されている (Circular Annex1,39)。この中の CLR109) は「CLEA (Contaminated Land Exposure Assessment Model)」 とよばれ、「人体への健康リスク (Human Health Risk)」を土壌污 染の程度と暴露時間によって評価する手法で、 i . 住宅地 (Residential)、 ii . 市民菜園（Allotment）、iii . 商業地／軽工業
地（Commercial/Light industrial）の 3 つの土地利用に関する

「包括的な除染シナリオ (Generic land use scenarios)」が用意さ れ、それぞれに「受容体」、「経路」、「暴露時間」などが決められて おり、「污染物質」の種類ごとに長期暴露による健康リスクを評価す るための指針「SGVs (Soil Guideline Values)」が用意されている。 以上が英国における「リスクベースの評価手法」である。

一方日本では、土壌污染調査の結果、環境省令基準に適合しない もので、「人の健康に係る被害が生じ、又は生ずるおそれがあるもの として政令で定める基準に該当する」ものに対し「要措置区域」が

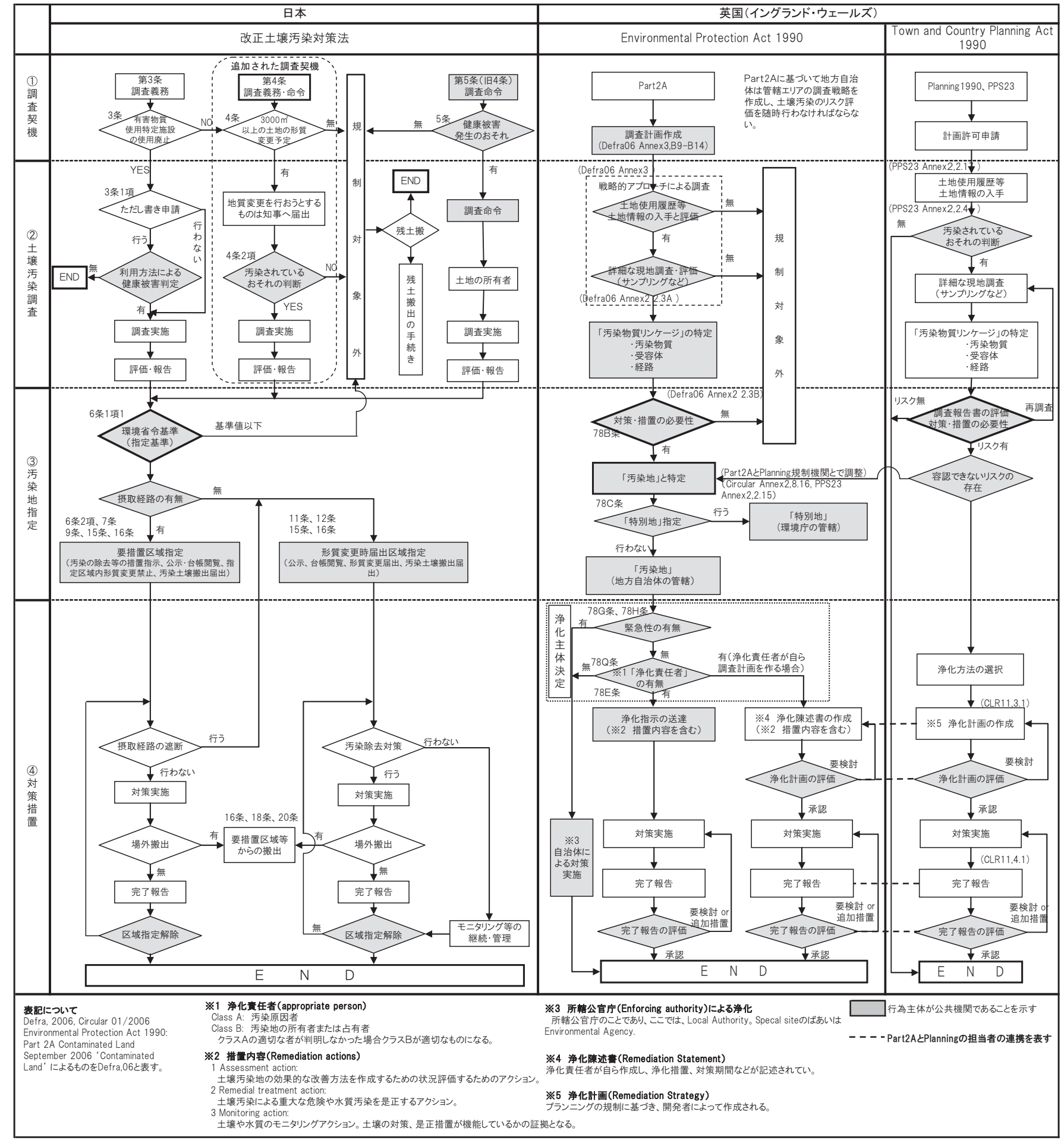

図 2 日英両国の法律による污染地の調查・対策フロー注9) 
指定され (改正法第六条)、それ以外のものは「形質変更時要届出区 域」に指定される (改正法十一条)。ここで、「人の健康に係わる被 害の生じるおそれ」とは、周辺地域の地下水利用状況（改正令第五 条一項一号イ）と当該污染地への人の立入りの可能性（改正第五条 一項一号口）の有無によってのみ判断され、これは英国の「リスク ベースの評価手法」とは異なる注 21 )。

\section{(4)対策・措置}

英国の Part II A の場合は「污染地」の指定後に浄化主体となる「浄 化責任者 (appropriate person)」が決定され、具体的な浄化方策を 命令する「浄化指示 (Remediation Notice)」が送達される（Part II A 78E-1)。一方で、既に浄化計画が準備されている場合などでは 「浄化責任者」等によって、「浄化陳述書（Remediation Statement)」が作成される (Circular Annex2,8.1-8.17)。また、「污 染地」の指定に際し、緊急性の高い場合（Part II A 78G-4、78H-4） および「浄化責任者」が発見できない場合は地方自治体と環境庁が それぞれ浄化措置を行うこととなる。具体的な措置内容に関して、 Circular $^{10)}$ では、DEFRA と「環境庁」によって作成された「CLR11

( Model Procedures for the Management of Land Contamination）11)」と呼ばれるモデルケースが示されている (Circular Annex1,39)。また、英国の Planning1990 では「許容で きないリスク」が明らかとなった場合も同様に、上述の CLR11 が 参照されており（PPS23,Annex2,2.42）、開発者等は個々に「浄化 計画（remediation strategy）」を作成し（CLR11,3.1）、地方自治 体の承認を受けなければならない。承認後、対策・措置を実施し、

「完了報告書, (verification report)」を提出し認可を受けることに なるが (CLR11,4.1)、ここでも PartII A と同様の措置が求められ る(PPS23,Annex2,2.51)。

一方日本では環境省令による污染物質の種類ごとの一律の基準に 沿った対策・措置を選択することになる（改正法施行規則第二十二 条)。

以上のことから英国では土壌污染対策に関する環境法令である EPA1990（Part II A）以外に都市計画規制（Planning1990、PPS23） において土壌污染調查と浄化対策が定められており、調查契機がよ り広範囲であること、それぞれの規制を所管する機関が「污染地」 の指定を討議し決定することなど都市計画規制との一体的運用が図 られていること、地方自治体が人体一の健康リスクの高いサイトを 優先的に調査する「戦略的アプローチ」をとっていること、CLEA など、現場ごとに浄化計画を作成し、「污染物質」、経路」、受容体」、

「暴露時間」の関係など、サイトごとのリスクを包括的に判断し対 策・措置を決める「リスクベースの評価手法」をとっている一方、 日本では環境省令による一律の基準に沿って対策・措置を行うこと などが異なっている。

\section{2 土壌污染地に係わる規模比較}

表 1 に日本と英国（イングランド・ウェールズ）の人口、国土面 積等と土壌污染地にかかわる推計規模等を示寸注 22 。土壌污染地の サイト数と面積の推計值に関しては、日英ともに敷地の使用用途か ら算定したもので、日本は環境省の報告書 ${ }^{1)}$ と保高の研究報告 ${ }^{12)}$ 、 英国は Environment Agency の報告書「Reporting the Evidence Dealing with Contaminated Land in England and Wales (以下
RECL） ${ }^{13}$ )」によるものである。また、土壌污染調査がされたサイ 卜数及び法令により污染地と指定されたサイト数は日本では、「平成 21 年度土袞污染対策法の施行状況及び土壌污染調查・対策事例等に 関する調查結果 ${ }^{14)}$ 」、英国は RECLによる注 23$)$ 。

まず英国（イングランド・ウェールズ）の国土面積は日本の 5 分 の 2 に当たる約 15 万 $\mathrm{km}^{2}$ であるが人口密度と DID 面積(Urban Areas) ${ }^{15)}$ はほぼ同程度である。次に、土壌污染地推計面積は英国 で約 30 万 ha、日本は約 11 万 ha であるが、サイト数は両国とも約 33 万サイトとほぼ同程度であり、1 サイトあたりの面積は英国の方 が大きく大規模である。またこのうち実際に土袞污染調查が実施さ れた件数は英国で約 3 万サイト、日本で約 1 万サイトであり、両国 の土壌污染推計サイト数に対する污染調查実施率は英国で 9.6\%、 日本で $3.1 \%$ であることから英国の方が 3 倍程度調査は進んでいる ことになる。このことは前節で示したように、日本の土壌污染の調 查契機には $3,000 \mathrm{~m}^{2}$ 未満の形質変更の契機が存在しないこと、自治 体による調查契機がないことなどが影響していると考えられる。

また、英国の Part II A により「污染地」に指定されたサイトと日 本の「旧土袞污染対策法」で指定された「指定区域」の累計サイト 数注 24$)$ はそれぞれ 781 サイト、435 サイトであり、污染調查件数 に対する指定率は英国で $2.5 \%$ 、日本で $4.2 \%$ である。このことは土 壌污染調查によって有害物質が判明した「污染地」の割合は日本の 方が英国に比べて高いことを示している。日本では 2010 年 4 月の 土壌污染対策法の改正に伴い、「指定区域」の改正が行われた。「改 正土壌污染対策法」に基づく「要措置区域」と「形質変更時要届出

表 1 日英の土壌污染サイトの推計規模 ${ }^{16}$ )

\begin{tabular}{|c|c|c|c|c|c|c|}
\hline & \multicolumn{3}{|c|}{ 英国(イングランド・ウェールズ) } & \multicolumn{3}{|c|}{ 日本 } \\
\hline 国土面積 (A) & 151,000 & $\mathrm{~km}^{2}$ & & 378,000 & $\mathrm{~km}^{2}$ & \\
\hline 人口集中地区(B) & 12,280 & $\mathrm{~km}^{2}$ & UA $* 1$ & 12,560 & $\mathrm{~km}^{2}$ & DID $* 2$ \\
\hline 人口 (C) & 52.04 & 百万 & & 127.28 & 百万 & \\
\hline 人口密度 (C/A) & 344 & $\widehat{\lambda} / \mathrm{km}^{2}$ & & 337 & $\widehat{\mathrm{Am}}$ & \\
\hline DID人口密度（C/B） & 4,238 & ᄉ $1 \mathrm{~km} 2$ & & 10,134 & $\stackrel{1 \mathrm{~km} 2}{1}$ & \\
\hline 土壌污染地推計面積(D) & 300,000 & ha & $\mathrm{PCS} * 3$ & 113,000 & ha & CS $* 4$ \\
\hline $\begin{array}{l}\text { 土壤污染地推計サイト数 } \\
\text { (E) }\end{array}$ & 325,000 & sites & PCS $* 3$ & 331,000 & sites & $C S * 5$ \\
\hline 土壤污染調査数(F) & 31,500 & sites & 検査 $* 3$ & 10,215 & sites & $\begin{array}{c}\text { 土壤污染調査 } \\
* 6\end{array}$ \\
\hline $\begin{array}{l}\text { 土鎄污染調査実施率(F／ } \\
\text { E) }\end{array}$ & 9.6 & $\%$ & & 3.1 & $\%$ & \\
\hline \multirow{4}{*}{$\begin{array}{c}\text { 法令指定污染地サイト数 } \\
\text { (G) (Part2A、改正土堙污 } \\
\text { 染対策法、旧土噇污染対 } \\
\text { 策法) }\end{array}$} & 781 & sites & $C L * 3$ & 435 & sites & 指定区域 $* 6$ \\
\hline & \multirow{2}{*}{\multicolumn{3}{|c|}{-}} & & & $\begin{array}{c}\text { 要措置区域 } \\
* 7\end{array}$ \\
\hline & & & & \multirow{2}{*}{\multicolumn{3}{|c|}{ - }} \\
\hline & 35 & sites & $\begin{array}{c}\text { Special sites } \\
* 3\end{array}$ & & & \\
\hline 法令指定污染地率 (G/F) & 2.5 & $\%$ & & 4.2 & $\%$ & \\
\hline $\begin{array}{l}\text { ブラウンフィールドの推計面 } \\
\text { 積 }\end{array}$ & 16,523 & ha & $\begin{array}{l}\text { Hard Core } \\
* 8\end{array}$ & 28,000 & ha & PBL $* 5$ \\
\hline $\begin{array}{l}\text { ブラウンフィールドの推計サ } \\
\text { イト数 }\end{array}$ & 2,000 & sites & \begin{tabular}{l|l} 
Hard Core \\
$* 8$
\end{tabular} & 80,030 & sites & PBL $* 5$ \\
\hline \multicolumn{7}{|c|}{$\begin{array}{l}\text { *1 DCLG's Census } 2001 \text { data and includes settlements of more than } 1000-- \text { equates to about } 9.5 \% \text { of } \\
\text { land area }\end{array}$} \\
\hline \multirow{3}{*}{\multicolumn{7}{|c|}{ 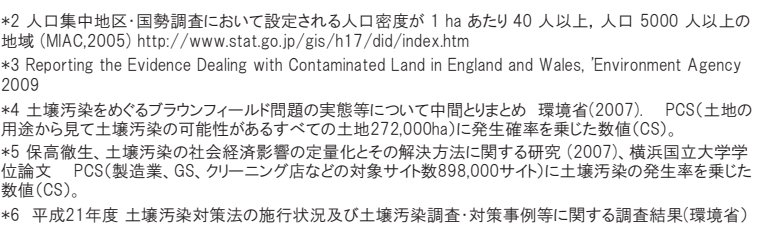 }} \\
\hline & & & & & & \\
\hline & & & & & & \\
\hline \multicolumn{7}{|c|}{ 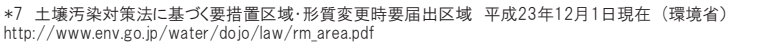 } \\
\hline
\end{tabular}


区域」 17)の合計は 515 サイトであり、その内「要措置区域」は 52 サイトとなる注 2 5)。

また、わが国におけるブラウンフィールドすなわち「土壌污染の 存在、あるいはその懸念から、本来、その土地が有する潜在的な価 值よりも著しく低い用途あるいは未利用となった土地 ${ }^{1)} 」 の$ 推計規 模は環境省 ${ }^{1)}$ と保高 ${ }^{12}$ ) の報告書によれば約 8 万サイト、約 2.8 万 ha と推計されている。その算出方法は、土壌污染推計サイト注 2 6) の内、污染対策にかかる費用がその土地の価格の $30 \%$ を超えるもの を土地売却が困難となるサイト、すなわち「潜在的なブラウンフィ ールド（以下 PBL）注 27)」として算定している。ただここには現 在操業中のサイトも含まれている。一方英国では序章で述べたとお りブラウンフィールドの定義が日本とは異なり、ここで「PBL」の 推計規模は公表されていないが、土袞污染が存在しない場合も含め 現在有効に使われていない土地或いは未利用の土地の情報は、EPS (現 HCA) の NLUD (National Land Use Database) によって Previously Developed Land（以下 PDL）として集計されており、 イングランドにおいて約 3.1 万サイト、 6.2 万 ha が登録されている

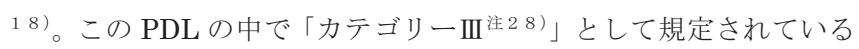
「ハードコアサイト (Hard Core Sites)」は再開発する際に企業の 収益が土壌污染対策を含む様々な障害要因によって事業採算性が確 保できないサイト19) として算定されている。これによると英国 (イ ングランド)の「ハードコアサイト」の推計規模は約 0.2 万サイト、 1.6 万 ha であるとされている。ここで日本の「PBL」と英国の「八 ードコアサイト」がいずれも事業採算の目処のたたない土地という 意味において共通の概念を有しているが、英国では土壌污染に起因 しない場合も含まれており、日本では現在操業中のサイトも含まれ ていることは留意する必要がある。

次に日英両国の土壌污染地の調查契機の比率を図 3 に示す。これ を見ると環境法令（旧土袞污染対策法とPartIIA）によるものは、 両国とも約 9\%であり、英国では大半 $(86 \%)$ が Planning1990に よって扱われている。英国ではほとんどの開発・建設行為は、「計画 許可 (Planning Permission)」を受けないと実施できないため、そ のプロセスにおいて土壌污染調査とその対策が行われることになる。 一方日本では自治体の「条例」によるものが $46 \%$ 、「自主調查」に よるものが $45 \%$ という結果になっている。ただし、このデータは旧 土壌污染対策法によるのもので、「条例」となっているのは、大規模 な土地の形質変更時などによる調查契機で一部の地方自治体の条例 （現在では改正法第四条に追加）で規定されている。また日本で自 主調查の割合が多いのは、環境省 ${ }^{1)}$ によると、「土地取引や企業資 産管理の場面などにおける自主的な土壌污染調查」があるためと指 摘している注 29 )。
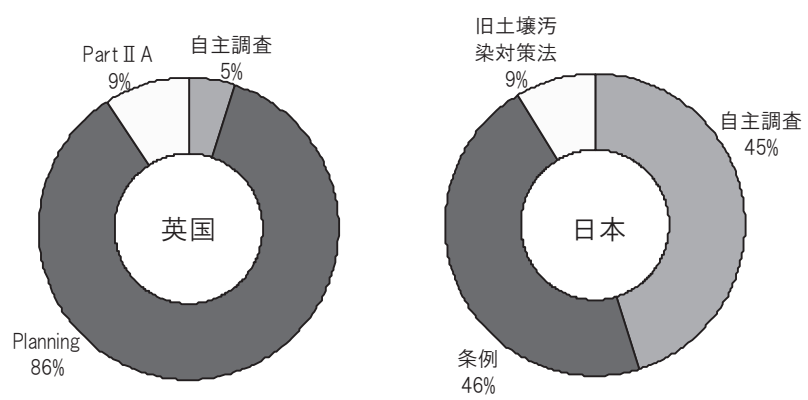

図 3 日英の土袞污染地の調查契機
以上のことから土壌污染調查の契機は両国ともに土地の開発や不 動産に係わる事業的契機が大半を占めていることを示している。特 に「自主調查」については土壌污染対策法の枠外であっても「污染 地」の把握が進むという点において好ましいことであるが、自主調 查は法や条例に基づかないため、「必ずしも統一された基準のもとに 実施されているわけではない（国土交通省）20)」こともあり、人 体一の健康リスクの観点からすれば、このような自主調査について もその基準を統一寸る必要があると考えられる注30)。

次に図 4 は両国における Part II A 及び旧土壌污染対策法が適用さ れた「污染地」の調查時の土地利用用途の割合をそれぞれ示したも のであるが、英国は住宅地が約 9 割を占めているのに対し、日本で は工場・事業所が大半 $(97 \%)$ を占めている。これは、日本におい ては旧土壌污染対策法の調查契機において特定施設（工場）の使用 廃止時が主たる調查対象である一方、英国の Part II A では調査主体 が自治体であることや前節で示した「戦略的アプローチ」から人体 への健康リスクの高い住居系施設のサイトが優先されたことなどが 考えられる注 14)。

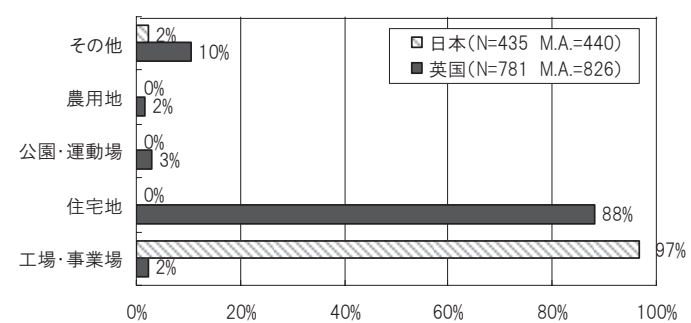

図 4 日英法律に基づく污染地の調查時用途注 31 )

図 5 は両国における「污染地」の污染原因となった過去の利用用 途の事業種の構成をそれぞれ示したものであるが、英国は廃棄物処 理業や電気・ガス・熱供給・水道業などの公的インフラ施設が多数 を占めている一方、日本では廃棄物処理業など公的インフラ施設は 少なく、金属、化学産業などの民間施設が多くを占めている。この ことは前述した日英の調查契機の違いや、産業構造の違いに起因し ているものと考えられるが、公的インフラ施設は日本でも同様に存 在するはずで、日本の調査件数がまだ英国よりも少ないことから、 今後このような施設に起因寸る土㙵污染が顕在化してくる可能性が あると考えられる。

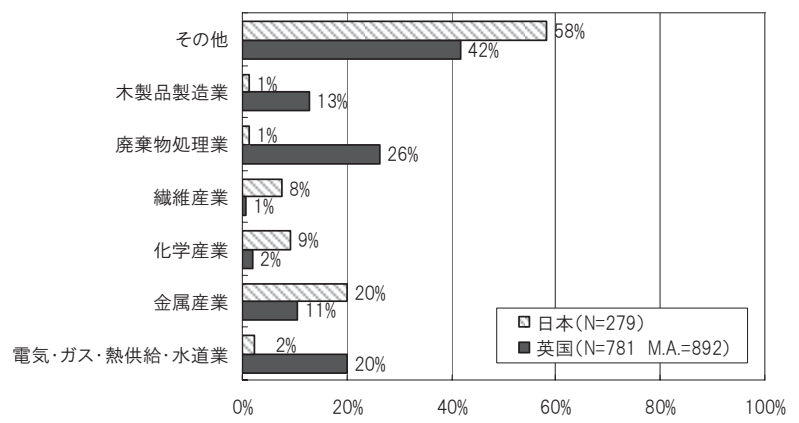

図 5 日英法律に基づく土㙥污染の原因となった業種注 321

図 6 に両国の土壌污染超過サイトのうち污染浄化対策が取られた サイトの措置内容の割合を示す。両国ともに「掘削除去」による対 策が約 6 割〜 7 割を占めている一方、英国では日本に比べて「封じ 
込め措置」が約 3 割と多くなっている。「封じ込め措置」による対 策はその後の污染管理が必要なことや地価への影響などから日本で はあまり採用されていない一方、英国では井水利用がほとんどない ことや対策費用の負担を軽減させる必要があったことなど注３３）が 推察されるが、英国の「リスクベースの評価手法」は当面の対策と して十分であっても污染浄化の先送りに繋がる可能性があることも 示唆している。

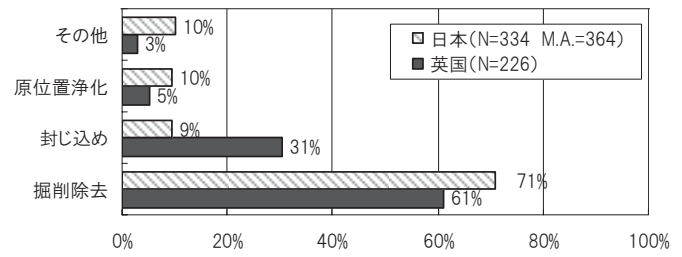

図 6 日英法律に基づく污染地の措置内容注 34 )

以上のことから、日本と英国の土壌污染推計サイト数はほぼ同程 度であるが、土壤污染推計サイト数に対する土壌污染調查実施率は 英国の方が日本よりも約 3 倍以上高く、污染調査が進んでいること、 両国ともに開発や事業的契機による調査が大半を占めているが、日 本の自主調査ではその評価方法の課題があること、また污染調査さ れたサイトの用途は英国ではほとんどが住宅地であることから健康 被害への対策が優先されていると考えられること、污染原因の比較 から今後日本でも公的インフラ施設に起因する土袞污染が顕在化す る可能性があること、污染対策に関しては両国とも「掘削除去」の 割合が高いが、英国では「封じ込め措置」の割合が高いことなどの 知見が得られた。

\section{4. まとめ}

本論では日本と英国の土壌污染に関連する法的枠組みと規模推計 の比較を行い、以下の結果を得た。

法的枠組みに関して

1. 土袞污染対策を規定している法律は日本では土壌污染対策法で あるのに対して、英国では環境法令である EPA1990（Part II A）以 外に都市計画規制の Planning1990 (PPS23) にも規定されており、 それぞれの規制を所管する機関が「污染地」の指定を討議すること、 共通のリスク評価手法（CLEA）を参照することなど土壌污染対策 と都市計画規制が一体的に運用されている。

2. 土壌污染地の調查主体は日本では土地の所有者等であるのに対 し、英国の Part II A ではその調查主体が地方自治体であり、人体へ の健康リスクを優先的に考える「戦略的アプローチ」をとっている。

3. 土壌污染の評価として英国では現場ごとの状況に応じて人体へ の健康リスクを包括的に判断する「リスクベースの評価手法」をと っているのに対して、日本では環境省令による一律の基準に沿って 評価を行っている。

規模推計などの比較に関して

1. 日本と英国の土壌污染地推計サイト数はいずれも約 33 万サイト と同程度であるが、污染地推計面積は英国の方が約 3 倍程度大きい。 また、推計サイトに対する土壌污染サイトの調查実施率は英国の方 が約 3 倍程度高く污染調査が進んでいる。このことは英国における 土袞污染の調查契機が日本よりも多く存在し、広範囲であるためと
考えられる。

2. 土袞污染の調査契機は両国ともに環境法令（EPA1990、旧土壌 污染対策法）による契機がいずれも約 $9 \%$ である一方、英国では都 市計画規制（Plannning1900）による契機が 86\%、日本では自治体 の条例（現在は改正法第四条）と自主調查による契機がそれぞれ約 45\%を占めており、両国とも開発や不動産に関わる事業的要因によ る調査契機が大半を占めている。

3. 環境省令による調査時の土地利用に関して、英国で住宅の割合 が多いのは調查主体が自治体であり、人体への健康リスクを優先的 に考える「戦略的アプローチ」に基づいていることなどが考えられ る。

4. 污染原因の比較から今後日本でも公的インフラ施設に起因する 土袞污染が顕在化する可能性がある。

5. 污染対策に関しては両国とも「掘削除去」の割合が高いが、英 国では「封じ込め措置」の割合が高く、英国の「リスクベースの評 価手法」は、当面の対策として十分であっても污染浄化の先送りに 繋がる可能性もある。

以上が日本と英国の土壌污染に関する法的枠組みと規模推計の比 較を通して得られた知見とわが国の土壌污染対策の位置付けである。 また今後の土袞污染対策のあり方を考える上で英国の法制度や取り 組みが参考になると思われる点は；

(1)戦略的アプローチとリスクベースの評価手法による土壌污染対策 (2)土㙥污染対策と都市計画規制との一体的運用

が考えられる。

(1)に関して英国では地方自治体が人体への健康リスクの高いサイト を優先的に調査する「戦略的アプローチ」と土培污染地の評価を現 場ごとの状況に応じて「污染物質」「経路」「受容体」「暴露時間」等 の関係によって包括的に判断する「リスクベースの評価手法」をと っているのに対して、日本では自治体による調查義務は規定されて おらず、土壌污染地の評価も環境省令による一律の基準で行われて おり、人体への健康リスクを優先的に考えるのであれば、英国のよ うに自治体が調查する仕組みを加えるとともに、土袞污染地の評価 に関しては、個々の事例ごとに包括的に人体への健康リスクを評価 する CLEA のような手法を取り入れることは重要である。ただしそ のために行政側の負担が増加すること、污染浄化の先送りに繋がる 可能性もあり、日英の行政システムの違いを考慮し、日本の状況に 合った手法の検討が必要である。

(2)に関して英国では土壌污染に関する環境法令である EPA1990 （Part II A）以外に、都市計画規制（Planning1990、PPS23）にお いて土裹污染調査と浄化対策が定められている一方、日本では旧土 袞污染対策法（2002 年）にはそのような調査契機が無く、2010 年 の改正によって大規模な土地の形質変更による調查契機が追加され たが、 $3,000 \mathrm{~m}^{2}$ 未満の土地は対象外であり、不動産に関する事業的 契機では「自主調査」に依存しているのが現状で、その場合の評価 基準が明確でない点が課題である。人体への健康リスクの観点から は、このような不動産的事業契機や将来の土地利用と連動した土壌 污染対策を行う必要があり、現行の都市計画規制との一体的な運用 によって、より広範囲な調查契機の拡充やそれぞれを所管する機関 が污染地指定、対策・措置を討議する枠組み作りなどが求められる。 


\section{謝辞}

本研究は科学研究費補助金 (20360270)、大林都市研究振興財団 の助成を受けており、英国の調查に関しては、RICS（Royal Institution of Chartered Surveyors) Education Trust の助成に加 え、Prof. Tim Dixon（University of Reading）および Prof. Paul Syms（Manchester University）から協力をいただいたことを記し 謝意を表します。

注

注 1)「Small Business Liability Relief and Brownfields Revitalization Act (文献 2)」において以下の上うに規定している。「Brownfields are real property, the expansion, redevelopment, or reuse of which may be complicated by the presence or potential presence of a hazardous substance, pollutant, or contaminant.」

http://www.epa.gov/brownfields/index.html(2012.3.24)

注 2) S.Alker は「The Definition of Brownfield（文献 3）」において以下の ように述べている。「A brownfield site is any land or premises which has previously been used of developed and is not currently fully in use, although it may be partially occupied or utilized. It may also be vacant, derelict or contaminated. Therefore a brownfield site is not available for immediate use without intervention. 」

注 3) English Partnerships は、2008 年 12 月に Homes and Communities Agency (HCA)の一部に統合されている。

注 4) English Partnerships $の$ Prof, Paul Syms は「The Brownfield Guide -A practitioner's guide to land reuse in English（文献 4)」において以下 のように述べている。「Over the past 12 to 15 years the term 'brownfield' has come into common usage in many industrialized and postindustrial nations around world. In some countries, for example in United States, brownfield is defiened by the presence of contamination. Elsewhere, including the United Kingdom, brownfield tends to be regarded as land that has been previously subject to physical development (other than agriculture) and where its reuse may be complicated by one or more factors, which may include contamination.」

注 5）日本の土壌污染対策関連法として「農用地の土壌の污染防止等に関寸 る法律（昭和 45 年法律第 139 号) 、「ダイオキシン類対策特別措置法（平 成 11 年法律第 105 号) 」、「水質污濁防止法（昭和 45 年法律第 138 号）」 などが挙げられるが、ここでは英国の Part II A に対応する「土壌污染対策 法（平成 14 年法律第 53 号）」に焦点を当てる。

注 6) Part II A は 1995 年「Environmental Protection Act 1990」に追加・ 挿入された。26 条からなり、土畩污染対策に関して規定されている。

注 7）PPS23 を含む Planning Policy Statement はキャメロン政権下では廃 止されており、National Planning Policy Framework（NPPF）に引き継 がれている。政府はこの NPPFによって、「簡素にわかりやすく示され、 住民と地域社会が計画に参画できるようにする」としており、土壌污染対 策に関する方針についても変更点があまり見られないため（各自治体にお いても)、これまでと変わらない取組が続けられる可能性が高いと推察され る。

注 8) なお本稿では日本の改正土袞污染対策法および施行令の条文はそれぞ れ「改正法第一条一項」「改正令一条」のように略記し、英国の Environmental Protection Act Part II A 及びそのガイダンス DEFRA, 2006 Circular 01/2006（文献 10）はそれぞれ「Part II A,1A-1」、「Circular, Annex1」のように示し、PPS23 については、その付属書 Planning Policy Statement 23: Planning and Pollution Control Annex 2: Development on Land Affected by Contamination（文献 22）之土壌污染対策の具体的 な指示書にあたる Model Procedures for the Management of Land Contamination Contaminated Land Report 11 （文献 11）をそれぞれ 「PPS23,Annex2,1.1」および「CLR11,1.1」のように示す。

注 9）調查対策フローの作成に当たり、日本の「土壤污染対策法」は、環境 省「土㙵污染対策法に基づく調查及び措置に関するガイドライン改訂版 2011 年、 11 ページ図 1.4-1」及び「社団法人東京建設業協会 土壌污染対
策フロー図」の資料を参考とし、「Part II A」に関しては主法文以外に $\lceil$ DEFRA」と沖田（文献 23）を参考に作成し、「PPS23」に関しては、付 属書（文献 22）及び CLR11（文献 11）参考にした。専門用語の日本語訳 は環境省の「The results of the survey on Enforcement Status of the Soil Contamination Countermeasures Act \& Numbers and trends of soil contamination investigations and countermeasures in the fiscal year 2004」を元に対応させた。

注 10） Part II A 78B-1 に「Every local authority shall cause its area to be inspected from time to time for the purpose- (a) of identifying contaminated land; and (b) of enabling the authority to decide whether any such land is land which is required to be designated as a special site.」と規定されている。

注 11）土地所有者等は「土地の所有者、管理者又は占有者」を示す。また、 法文七条一項の但し書きにおいて「当該土地の所有者等以外の者の行為に よって当該土地の土壌の特定有害物質による污染が生じたことが明らかな 場合であって、その行為をした者に污染の除去等の措置を講じさせること が相当であると認められ、かつ、これを講じさせることについて当該土地 の所有者等に異議がないときは、環境省令で定めるところにより、その行 為をした者に対し、指示するものとする。」と規定されている。

注 12）A)特定施設の使用廃止時とは「使用が廃止された有害物質使用特定施 設に係る工場又は事業場の敷地であった土地が生じた時」、B)形質変更時 とは「土壌污染のおそれがある土地の形質の変更が行われる場合」、C)健 康被害発生時とは「土壤污染の特定有害物質による污染により人の健康に 係わる被害が生ずるおそれがあるものとして政令で定める基準に該当する 土地があると認める時」を示す。

注 13) Circular Annex2 2.3A に「Before the LOCAL AUTHORITY can make the judgment that any land appears to be CONTAMINATED LAND, the authority must satisfy itself that a POLLUTANT LINKAGE exists in relation to the land. A POLLUTANT LINKAGE requires each of the following to be identified: (a) a CONTAMINANT; (b) a RECEPTOR; and (c) a PATHWAY CAPABLE of exposing a receptor to the contaminant. と規定されている。

注 14）例えば、マンチェスター市（文献 22）においては、PG01（Risk Prioritisation Methodology）と呼ばれる GIS を用いて、土壌污染の可能 性のある 6500 サイトを特定したが、これを即時に全て調查することは予 算、人員、時間などの制約により困難として、人体への健康リスクによる 優先順位をつけて調査していく戦略的アプローチがとられている。英国は 産業革命以後かなり時間が経過し、土壌污染に関する法律が成立するかな り前から、すでに土地利用転換がなされたケースも多く、長期残存の污染 地も多いため、健康リスクの優先順位から住宅での取組が多くなっている と推察される。

注 15）改正法第三条第一項の但し書きで「環境省令で定めるところにより、 当該土地について予定されている利用の方法からみて土壤の特定有害物質 による污染により人の健康に係る被害が生ずるおそれがない旨の都道府県 知事の確認を受けたときはこの限りでない」として猶予措置が規定されて いる。

注 16）土壌污染対策法施行規則（令第二十九号）の第三条二項において「土 壤のその他の試料の採取及び測定」方法が規定されている。

注 17）法第五条第二項において、「当該調査等を命ずべき者を確知すること ができず、かつ、これを放置することが著しく公益に反すると認められる」 場合には自治体による土袞污染調查の代行執行を規定している。

注 18）日英両国の法律の法文にみる定義は右表の通り。英国の場合、「重大 な危害」が污染物質リンケージにあたる。

\begin{tabular}{|c|c|}
\hline \multirow{3}{*}{$\begin{array}{l}\text { 改正法第六条 } \\
\text { 第一項 }\end{array}$} & 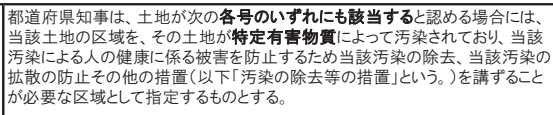 \\
\hline & 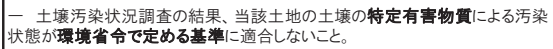 \\
\hline & 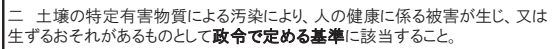 \\
\hline \multirow{3}{*}{$\begin{array}{l}\text { Part II A,78 A } \\
-2\end{array}$} & $\begin{array}{l}\text { 地中、地上若しくは地下に存在する物質に起因し、その土地を管轄する地方当 } \\
\text { 同によってい下のうな状態であると地をいう。 }\end{array}$ \\
\hline & $\begin{array}{l}\text { a) 重大な危害(signigicant harm)が引き起こされている若しくはそのような損 } \\
\text { 害を引きき起しれるおがある状態。もしくは、. }\end{array}$ \\
\hline & 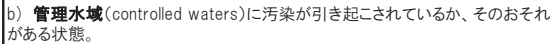 \\
\hline
\end{tabular}


注 19) Circular Annex3 A17 に「a “pollutant linkage” means the relationship between a contaminant, a pathway and a receptor, and a "pollutant" means the contaminant in a pollutant linkage. Unless all three elements of a pollutant linkage are identified in respect of a piece of land, that land should not be identified as contaminated land.」と規 定されている。

注 20）CLR は非法定ガイダンスであり、これに従う義務はないが、法定ガ イダンスである Circular2006 に推奨されていることから、一般的には CLR に沿って対策・措置が実施されると考えられる。

注 21）日本では、污染物質の人への暴露経路についての検討は周辺地下水の 有無（令第五条一項一号イ）と当該污染地への人の立入りの可否（令第五 条一項一号口）によって行われる一方、英国では污染物質と受容体への経 路の検討は周辺地下水の有無及び当該敷地への立入りの可否の検討だけで なく、発見された污染物質それぞれについて受容体との経路が検討され、 これらの個々の具体的なリンケージについて措置内容が指示される。

注 22）文献 16 の Table 1. Comparative analysis of brownfields: England and Japan (based on 2007 data adapted from Dixon et al, 2010).を参照 ウェールズを加えて修正。

注 23）「平成 21 年度土壌污染対策法の施行状況及び土壌污染調查・対策事 例等に関する調査結果」は旧土壌污染対策法のデータであり、平成 22 年度 版も平成 24 年 3 月に公表されているが、調査時の土地利用状況や法に基づ かない事例の内訳などが公表されていないため、本稿では平成 21 年度版の 調査結果を利用する。

注 24）日本の数值は法施行日（2003 年 2 月 15 日）以降、改正以前 2010 年 3 月 31 日 $(2010$ 年 4 月 1 日改正施行) までの約 7 年間の累計件数であり、 英国の数值は Part2A の施行日（イングランド 2000 年、ウェールズ 2001 年) から 2007 年 3 月 31 日までの約 7 年間の累計数值。

注 25）ここで、「要措置区域」は環境省令の基準を超過する有害物質が存在 し、そのことにより人の健康に係わる被害が生じるまたはそのおそれがあ る土地のことであり、これはただちに対策・措置がとられるべきであると いう点において英国の「污染地」と同様である。一方「形質変更時要届出 区域」は環境省令の基準を超過する有害物質が存在するが、ただちに人の 健康を害する危険がないものをいい、これは英国の「污染地」の定義とは 異なっている。

注 26）土壌污染地推計サイトとは全製造業事業所、クリーニング店、ガソリ ンスタンドを対象とし、事業所数が最も多かった年度のデータに土壌污染 の業種別発生確率を掛けた数值。

注 27） PBL とは土壌污染地推計サイトのなかで、土地価格に対する土壌污染 対策費用の比率が三割を上回るサイトとして算出されている。

注 28）EPS は PDL のカテゴリーを以下の図（文献 19）のように4つに分類 している。

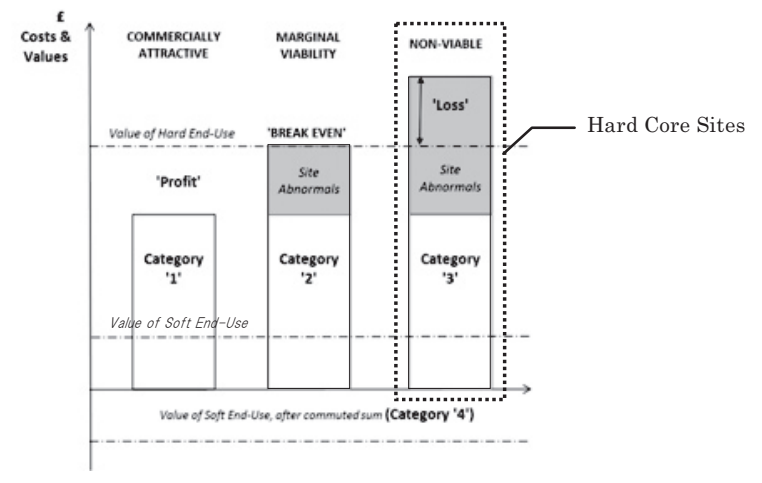

注 29）この理由として中間取りまとめ（環境省）では、「2002 年に国土交通 省の『不動産鑑定評価基準』の改正が行われ、『不動産の価格を形成する要 因 (第 3 章)』の中で土壌污染の有無及びその状態調査の項目が追加され、 『土壌污染が存することが判明した不動産については、原則として污染の分 布状況、除去等に要する費用等を他の専門家が行った調查結果等を活用し て把握し鑑定評価を行うものとする』と改正された。さらに、(社) 日本不 動産鑑定協会は、土㙵污染に関わる不動産鑑定評価上の運用指針 I (2002.12)、II (2004.10) として『独自調査の結果に基づく判断とともに鑑定
評価証に明記し、独自調査の内容、結果を記載した資料等については鑑定 評価証とともに保管しなければならない』と定めている。また、宅地建物 取引業法においても 2004 年に改正され重要事項説明の中で土塎污染対策 法が加えられた。」こが指摘されている。

注 30）改正土壌污染対策法では新たに土地の所有者等は、自主調査等により 有害物質による污染の状況について調查した結果、当該土地の土壌の特定 有害物質による污染状態が環境省令で定める基準に適合しない場合は、環 境省令で定めるところにより、都道府県知事に対し、当該土地の区域につ いて形質変更時要届出区域の指定の申請が可能となったが (第十四条一項) これは事業者による任意の手続きに留まっている。

注 31）文献 13、14 を元に日英の用語を以下のように対応させた。

\begin{tabular}{|c|c|c|}
\hline & 日本 & 英国 \\
\hline 工場·事業場 & 工場·事業場敷地、工場·事業場跤地 & Industrial premises \\
\hline 住宅地 & 住宅地 & Housing \\
\hline 公園·運動埸 & 公園·運動場 & Park and recreation \\
\hline 農用地 & 農用地 & Agriculture \\
\hline その他 & 廃莱物処分場跡地、道路、河川敷、山林、不明、その他 & Derelict land, Commercial premises, No information. Other \\
\hline
\end{tabular}

また、Circular Annex2 3.3 に Taking a strategic approach enables the LOCAL AUTHORITY to identify, in a rational, ordered and efficient manner, the land which merits detailed individual inspection, identifying the most pressing and serious problems first and concentrating resources on the areas where CONTAMINATED LAND is most likely to be found.」とあることから、調査時用途が住宅地に集中し ていることのひとつの要因に英国の地方自治体が合理的かつ効果的に調査 が行うため、優先的に過去に産業用途で使用されていた土地に住宅が建設 されたケースを調査していることが示唆される。

注 32）文献 13、14 を元に日英の用語を以下のように対応させた。

\begin{tabular}{|c|c|c|}
\hline & 日本 & 英国 \\
\hline 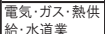 & カ゚ス業、水道業 & Energy industry \\
\hline 金属産業 & 鉄銅業、非鉄金属製造業、金属製品製造業 & Metal industry \\
\hline 化学産業 & 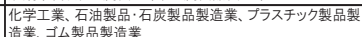 & Chemical industry \\
\hline 紼維産業 & 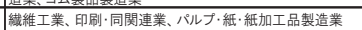 & Textiles, printing and coating industries \\
\hline 廃莱物処理業 & 廃辚软贬理業 & Waste management industry \\
\hline 木製品製造業 & 木材·木製品製造業、家具·装備品製造業 & Timber processing industry \\
\hline Zの他 & 文葑13)の表30记載て上記以外の業種 & Mineral industry. Othert+ \\
\hline
\end{tabular}

注 33）対策後も現地の維持管理を続ける必要があるが、污染土鎄の搬出を伴 わないため、運搬中や搬出先での二次被害のリスクは減り、対策費用は安 く済むなどのメリットもある。

注 34）文献 13、14 を元に日英の用語を以下のように対応させた。

\begin{tabular}{|c|c|c|}
\hline & 日本 & 英国 \\
\hline 掘削除去 & 掘削除去 & Excavation and off-site disposal \\
\hline 封し込め & 原位置封じ込め、遮水工封じ込め、遮断工封じ込め、盛土、 & Containment \\
\hline 原位置浄化 & 原位置净化 & $\begin{array}{l}\text { In-situ bioremediation, In-situ chemical treatment, In-situ } \\
\text { physical treatmen }\end{array}$ \\
\hline その他 & 文献13)の表19の洋化措置のうち上記以外 & 文献12)のfig11,fig12の䋛化措置のうち上記以外 \\
\hline
\end{tabular}

\section{参考文献}

1）環境省 土壌污染をめぐるブラウンフィールド対策手法検討調査検討会: 土壌污染をめぐるブラウンフィールド問題の実態等について一中間とりま とめ一,2007.3

2) House of Representatives: Small Business Liability Relief and Brownfields Revitalization Act (HR2869), Washington DC.USA, 2001

3) Sandra Alker et.al: The Definition of Brownfield, Journal of Environmental Planning and Management, 43(1), pp.49-69, 2000

4) English Partnerships, Paul Syms: The Brownfield Guide -A practitioner's guide to land reuse in English, 2006.10

5）宮川智子：跡地利用・再開発と連携した土堹污染対策の計画の検討, 日本 建築学会計画系論文集, 第 565 号, pp.209-216, 2003.3

6）宮川智子：旧産業地域における景観戦略と低・未利用地の環境再生に関す る研究, 日本建築学会計画系論文集, 第 642 号, pp.357-362, 2008.2

7）原口唯・土居義岳：グリニッジ・ミレニアム・ビレッジ計画に関する報告 グリニッジ半島の土地利用における変遷, 日本建築学会研究報告, 九州支 部第 49 号, pp.661-664, 2010.3

8）村木美貴・小倉裕直：サスティナブル・デベロップメント実現のための都 市計画のあり方に関する研究 日英の環境負荷に着目した低・未利用地の再 生について, 日本都市計画学会都市計画論文 38(3), pp.331-336, 2003.10

9) Department for Environment, Food and Rural Affairs, Environment Agency: The Contaminated Land Exposure Assessment Model (CLEA) 
Technical basis and algorithms, 2002

10)Department for Environment, Food and Rural Affairs: Circular 01/2006 Environmental Protection Act 1990 Part II A Contaminated Land September 2006 'Contaminated Land', 2006

http://archive.defra.gov.uk/environment/quality/land/contaminated/doc uments/circular01-2006.pdf, 2013.1.23 参照

11) Environment Agency: Model Procedures for the Management of Land Contamination Contaminated Land Report 11, 2004

12）保高徹生：土埪污染の社会経済影響の定量化とその解決方法に関する研 究, 横浜国立大学博士学位論文,2007.3

13) Environment Agency: Reporting the Evidence Dealing with Contaminated Land in England and Wales, 2009

14）環境省：平成 21 年度 土壌污染対策法の施行状況及び土壌污染調查・対 策事例等に関する調査結果, 2011

15) Communities and Local Government: Population for England and Wales from 2001 Census, 2001

16) Timothy Dixon, Noriko Otsuka, Hirokazu Abe: Critical success factors in urban brownfield regeneration: an analysis of 'hardcore' sites in Manchester and Osaka during the economic recession (2009-10), Pion,
Environment and Planning A, volume 43(4), pp.961-980, 2011.5 17）環境省：土壌污染対策法に基づく要措置区域・形質変更時要届出区域, http://www.env.go.jp/water/dojo/law/rm_area.pdf, 2012.1.30 参照

18) Homes and Communities Agency: Previously-Developed Land that May be Available for Development. Results from the 2009 National Land Use Database of Previously-Developed Land in England,

Warrington: Homes and Communities Agency, 2011

19) English Partnerships: Towards a National Brownfield Strategy, 2003 20）国土交通省土地・水資源局 土地政策課土地市場企画室：土塞污染地に心

ける土地の有効利用等に関する研究会 中間とりまとめ, 2008.4

21）仲田孝仁: 英国土壌污染地法の諸問題, 慶応義塾大学法学部内法学研究 会, 法学研究, 第八十一巻, 第十二号, pp.457-506, 2008.12

22) Manchester City Council Contaminated Land Section Environmental Services: Manchester City Council Contaminated Land Strategy

Updated March 2011, 2011

（2012年 5 月31日原稿受理，2013年 1 月22日採用決定） 